\title{
Organochlorine Compounds and Trace Elements in Streambed Sediment and Fish Tissue, South Platte River Basin-Colorado, Nebraska, and Wyoming
}

\section{INTRODUCTION}

Concentration data for organochlorine compounds and trace elements in streambed sediment and fish tissue collected throughout the South Platte River Basin as part of the U.S. Geological Survey's National WaterQuality Assessment (NAWQA) Program were evaluated to determine the following: (1) which organochlorine compounds and trace elements occurred most frequently, (2) whether detection frequencies and concentrations differed among land uses, (3) how measured concentrations related to established standards and guidelines, and (4) whether there was any relation between concentrations in streambed sediment and fish tissue. Streambed sediment and fish . tissue were collected at 23 sites, which were selected on the basis of physiography, geology, and land-use characteristics.

-Banned pesticides, including DDE, DDT, DDD, and PCB's, frequently were detected in fish tissue.

-DDE, DDT, and chlordane compounds were detected in some streambed sediment.

-The greatest number of detections of organochlorine compounds, as well as the highest concentrations in streambed sediment and fish tissue, occurred in streams affected by urban and mixed land use.

- Concentrations of DDT, PCB, and total chlordane in fish tissue exceeded the National Academy of Sciences/National Academy of Engineering guidelines for consumption by fish-eating wildlife at several sites.

- Concentrations of arsenic, cadmium, chromium, copper, iron, lead, manganese, silver, uranium, and zinc in streambed sediment at sites affected by mining activities exceeded background concentrations.

-Concentrations of aluminum, arsenic, cadmium, chromium, copper, lead, manganese, selenium, silver, and zinc in streambed sediment in urban and mixed land-use areas exceeded background concentrations.

-There are no Federal guidelines or standards for trace-element concentrations in streambed sediment or fish liver.
U.S. Department of the Interior-U.S. Geological Survey

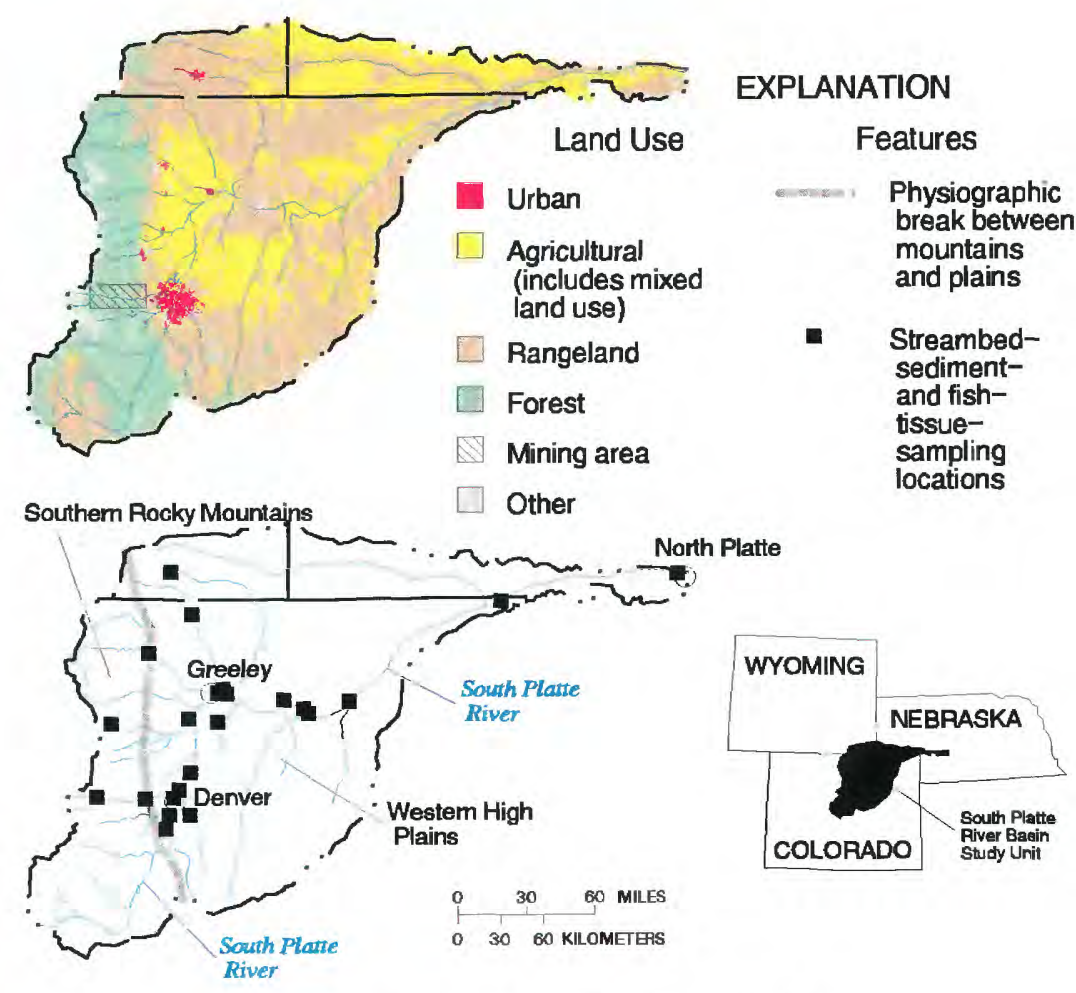

The South Platte River Basin Study Unit.

\section{ORGANOCHLORINE COMPOUNDS}

Hydrophobic organochlorine compounds (OC's) tend to sorb to organic carbon in suspended and streambed sediment rather than to dissolve in the water column. Because of this characteristic, these compounds tend to be present in sediment in concentrations that are orders of magnitude greater than those in the water column. Bioaccumulation tends to further concentrate organochlorine compounds in fish tissue.

\section{Which organochlorine compounds are detected, and in what media are detections most frequent?}

Of those organochlorine compounds analyzed for in streambed sediment and whole fish tissue, more were detected in fish than in streambed sediment. Those organochlorine compounds most frequently detected in whole fish tissue included DDE and DDT (detected in more than 75 percent of samples), DDD and total PCB's (detected in more than 50 percent of samples), and total chlordane, Dacthal, and dieldrin (detected in more than 25 percent of samples).

In streambed sediment, trans-chlordane, cis-chlordane, DDE, and DDT were detected at more than 25 percent of the sites. Other organochlorine compounds were detected at less than 25 percent of the sites. 
PERCENT DETECTIONS IN STREAMBED SEDIMENT AND FISH TISSUE

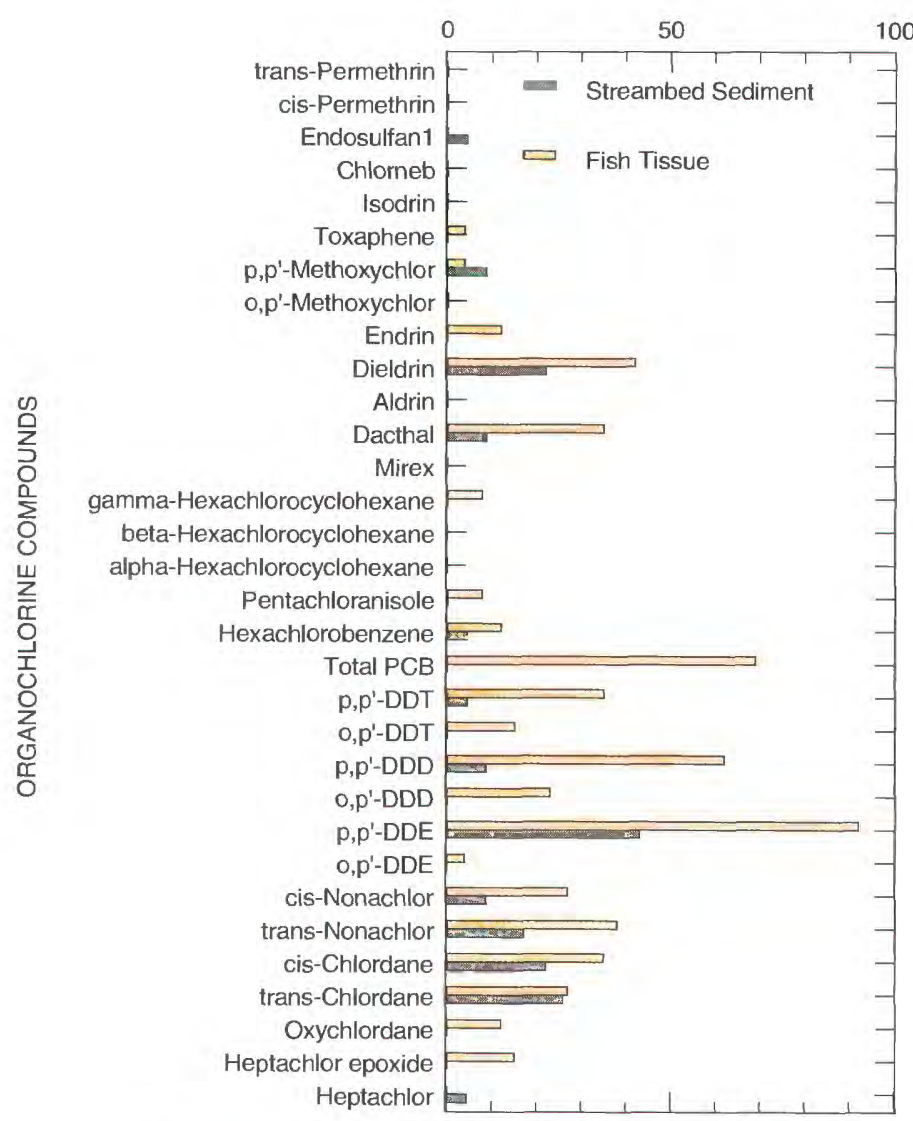

Organochlorine compounds detected in streambed sediment and whole fish tissue.

\section{Do concentrations of organochlorine compounds differ among land uses?}

The number and concentration of organochlorine compounds detected in streambed sediment and fish tissue at individual sites were related to local land uses. No more than one organochlorine compound was detected at sites located in forest, built-up (lowdensity residential), and rangeland land uses. The largest number and highest concentrations of organochlorine compounds were detected in streambed sediment and fish tissue from urban land-use sites and agricultural sites affected by wastewater discharges (defined as mixed land use in this study).

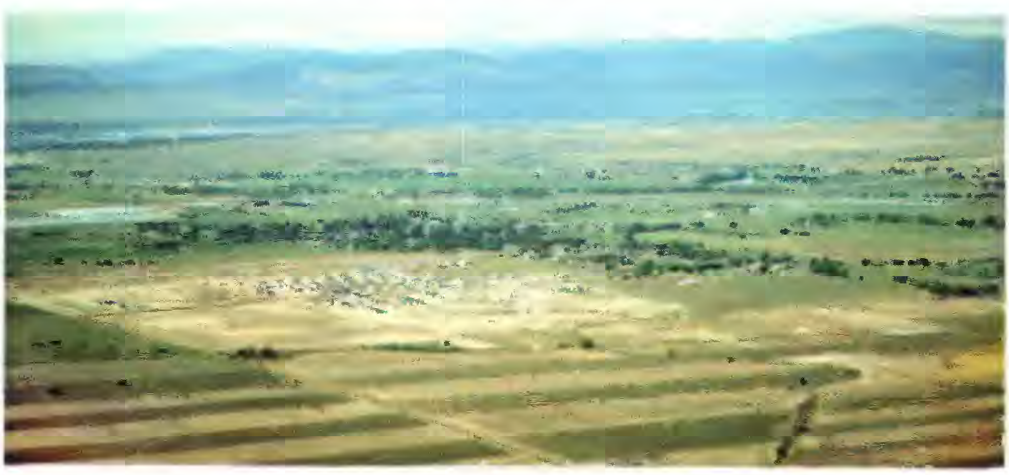

Mixed land use was designated for sites that are predominantly agricultural, but water quality is substantially affected by discharges from upstream wastewater-treatment plants.

\section{How do concentrations of organochlorine compounds compare to established standards and guidelines?}

Although organochlorine concentrations in fish tissue did not exceed the Food and Drug Administration (FDA) guidelines for consumption of fish by humans, the National Academy of Sciences/ National Academy of Engineering guidelines for consumption of fish by wildlife were exceeded for DDT in common carp at two mixed land-use sites (more than double the guideline of $1,000 \mu \mathrm{g} / \mathrm{kg}$ at one site), for PCB in common carp at an urban land-use site (more than double the guideline of $1,000 \mu \mathrm{g} / \mathrm{kg}$ ), for PCB in white sucker at a mixed land-use site, and for total chlordane in white sucker at a mixed land-use site (Heiny and Tate, 1997). Animals eating fish in these areas may be at risk. There are no Federal standards or guidelines for organochlorine concentrations in streambed sediment.

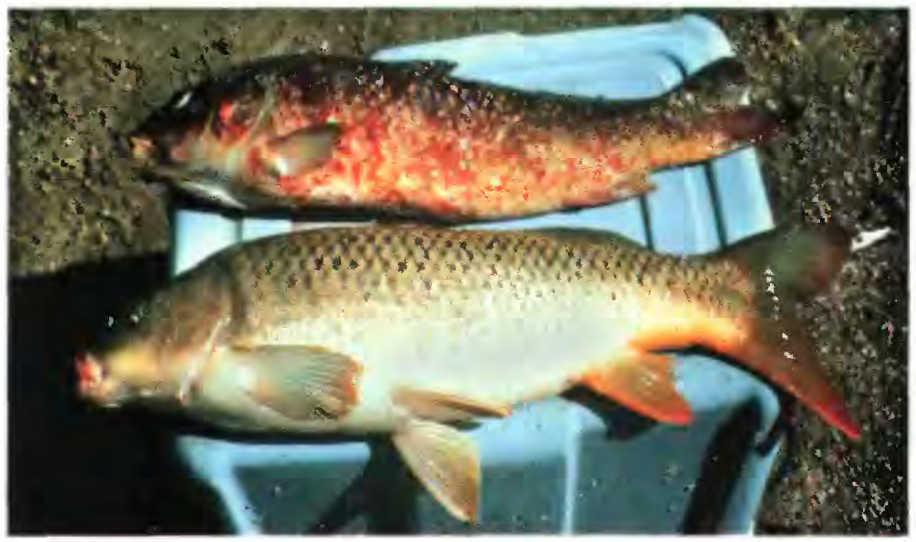

The cumulative effects of organochlorine compounds on biota are unknown. Shown here are healthy (bottom fish) and unhealthy (top fish) carp from the same site on the South Platte River.

\section{How do concentrations of organochlorine compounds in streambed sediment relate to concentrations in fish tissue?}

Concentrations of organochlorine compounds were one to two orders of magnitude greater in fish tissue than in streambed sediment. Additionally, more compounds were detected in fish tissue than in streambed sediment.

\section{TRACE ELEMENTS}

Trace elements concentrate in fine-grained streambed sediment and are bioaccumulated in fish tissue. In addition to human-induced contamination sources, trace-element concentrations are directly related to the geologic source of the sediment, and because small amounts of trace elements are necessary to biologic health, care must be taken in determining if concentrations are a water-quality concern. A background streambed-sediment concentration was determined for each element from a probability distribution of the concentration of that element in each sample. Sites with elevated concentrations were then identified. For fish liver, concentrations were compared to the mean concentration for each species collected (brown trout, white sucker, or common carp). 


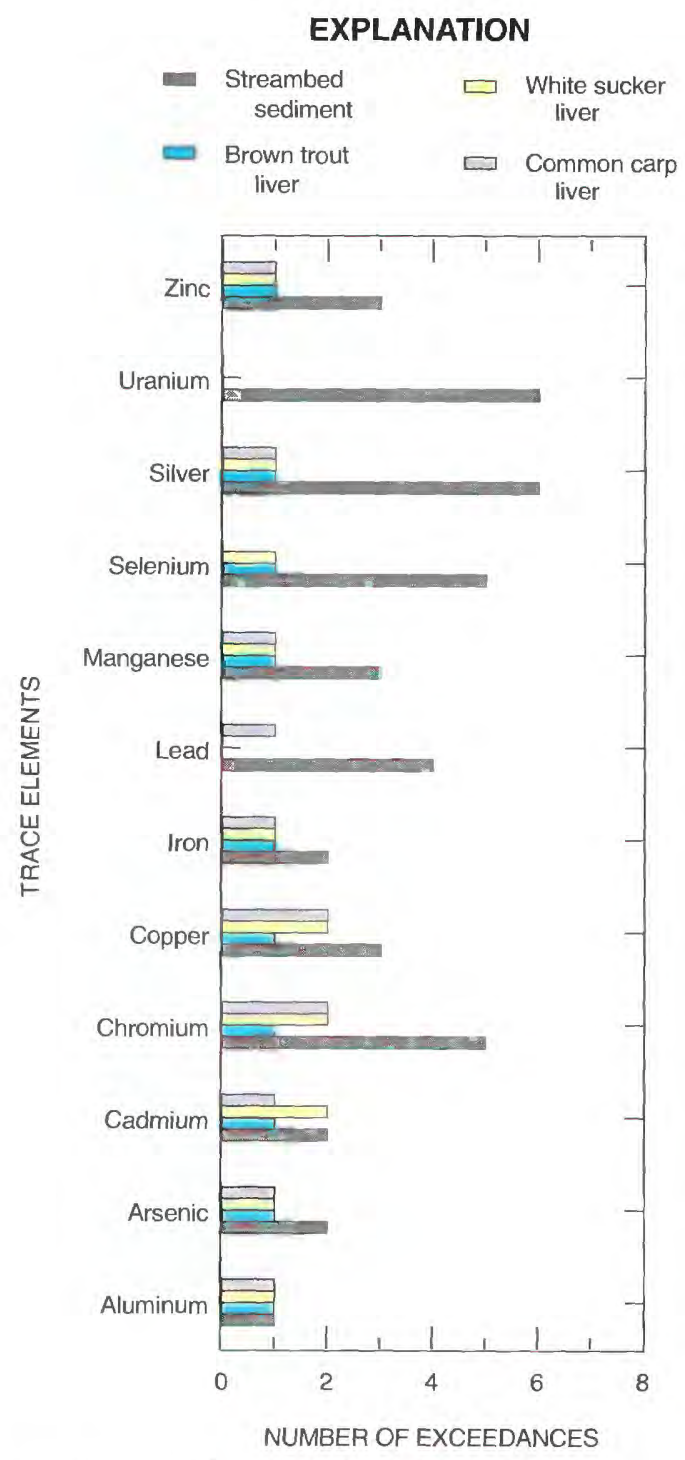

Trace elements detected above background concentrations in streambed sediment and above mean concentrations in fish liver.

\section{Which trace elements are detected above background concentrations, and in what media are detections most frequent?}

Silver and uranium in streambed sediment exceeded background concentrations at five or more sites (in agricultural, mining, mixed, and urban land uses). Concentrations of arsenic, cadmium, chromium, copper, iron, lead, manganese, selenium. and zinc in streambed sediment exceeded background concen-

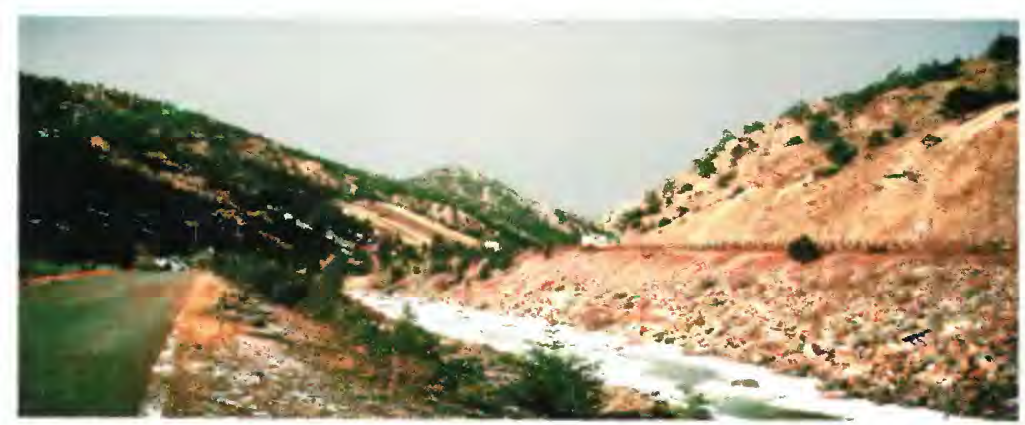

Past and present mining activities are potential sources of trace elements to streambed sediment and biota. trations at up to three sites. Aluminum concentrations exceeded the background concentration for streambed sediment at only one site. Cadmium, chromium, copper, iron, manganese, selenium, silver, and zinc were detected in fish liver at all sites but rarely were greater than mean concentrations.

\section{Do concentrations of trace elements differ among land uses?}

The most important land-use effect on concentrations of trace elements in streambed sediment is mining. All trace elements examined in this study, except selenium and uranium, exceeded background concentrations in mining areas. Concentrations of aluminum, selenium, silver, and zinc in streambed sediment exceeded background concentrations in urban land-use areas, and concentrations of arsenic, cadmium, chromium, copper, manganese, and silver in streambed sediment exceeded background concentrations in mixed land-use areas.

In fish liver, concentrations of aluminum and cadmium were highest in areas affected by mining. Arsenic and iron concentrations were higher in urban land-use areas than in mixed and agricultural land-use areas. whereas concentrations of cadmium, copper, selenium, silver, and zinc were higher in agricultural land-use areas than in mixed and urban land-use areas.

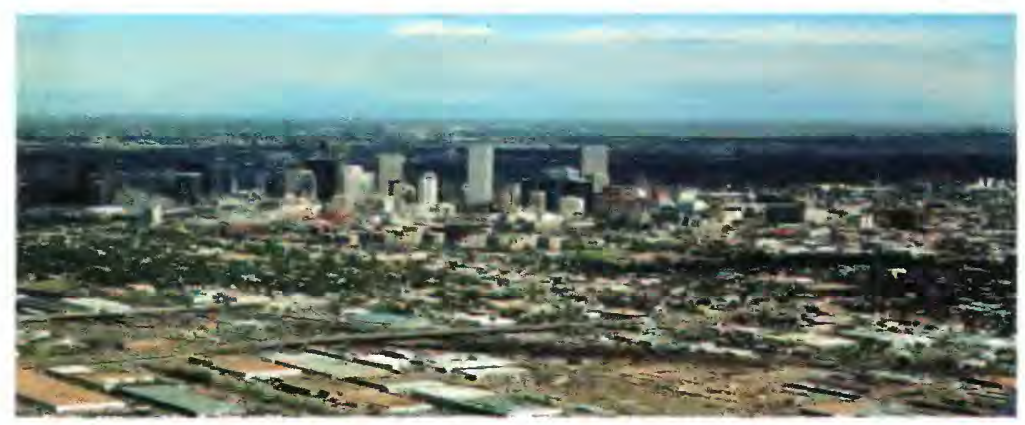

Urban and industrial areas are potential sources of trace elements to the river.

\section{How do trace-element concentrations compare to established standards and guidelines?}

At present, there are no State or Federal guidelines for trace-element concentrations in streambed sediment or fish liver, making assessment of risk factors difficult.

\section{How do concentrations of trace elements in streambed sediment relate to concentrations in fish liver?}

Trace-element concentrations generally were an order of magnitude greater in streambed sediment than in fish liver (aluminum and iron were several orders of magnitude greater), with the exception of selenium concentrations, which were an order of magnitude greater in fish liver than in streambed sediment. Different fish species bioaccumulate trace elements in their livers at different rates. Therefore, direct comparisons cannot be made between streambed sediment and fish species or among concentrations in different fish species. 


\section{SUMMARY}

Measuring concentrations of organochlorine compounds and trace elements in streambed sediment and whole fish tissue at the same sites offers a comprehensive picture of the persistence of these contaminants in the environment and their relation to land-use practices. Although most organochlorine compounds analyzed in this study have not been used since 1972 to 1988 , they still are present in the environment, and in a few instances, persist at concentrations above levels of concern. The greater number and higher concentrations of organochlorine compounds detected in streambed sediment and whole fish tissue at mixed land-use sites represent the cumulative effects of multiple land uses at a site and make it difficult to distinguish sources of contaminants at those sites.

Because trace elements naturally are present in all streambed-sediment samples but do not accumulate at the same rates in different fish species, different patterns of trace-element concentrations occur between streambed sediment and fish liver, and these patterns make it difficult to relate to land use. Background trace-element concentrations were determined for streambed sediment and then used to locate sites with elevated concentrations. Trace-element concentrations in streambed sediment in mined areas were elevated and possibly of concern, and some elements in streambed sediment in urban areas also had elevated concentrations.

This fact sheet is a summary of two reports describing the results of bed-sediment and fish-tissue sampling by the South Platte River Basin NAWQA Study Unit.

Heiny, J.S., and Tate, C.M., 1997, Concentration, distribution, and comparison of selected trace elements in bed sediment and fish tissue in the South Platte River Basin, USA, 1992-93: Archives of Environmental Contamination and Toxicology, v. 32, p. 246-259.

Tate, C.M., and Heiny, J.S., 1996, Organochlorine compounds in bed sediment and fish tissue in the South Platte River Basin, USA, 1992-93: Archives of Environmental Contamination and Toxicology, v. 30, p. 62-78.

\section{The NAWQA Program}

In 1991, the U.S. Geological Survey, U.S. Department of the Interior, began a National Water-Quality Assessment (NAWQA) Program. The longterm goals of the NAWQA Program are to describe the status of and trends in the quality of a large representative part of the Nation's surface- and groundwater resources and to identify the major factors that affect the quality of these resources. In addressing these goals, the NAWQA Program will produce waterquality information that is useful to policymakers and managers at Federal,

State, and local levels.

Studies of up to 60 hydrologic systems that include parts of most major river basins and aquifer systems are the building blocks of the national assessment. The 60 study units range in size from less than 1,000 to more than 60,000 square miles and represent 60 to 70 percent of the Nation's water use and population served by public water supplies. Twenty investigations began in 1991,15 investigations began in 1994, and at least 12 are scheduled to begin in 1997.
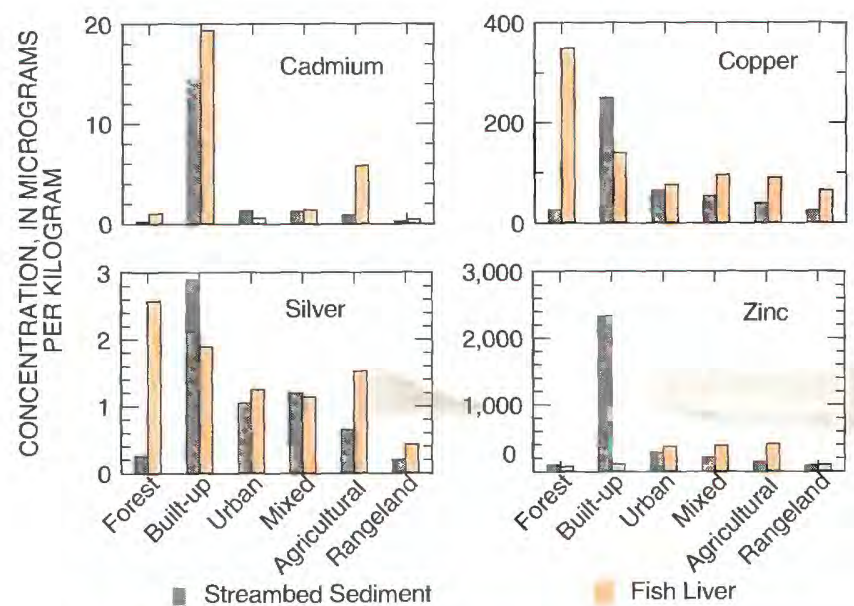

- Streambed Sediment
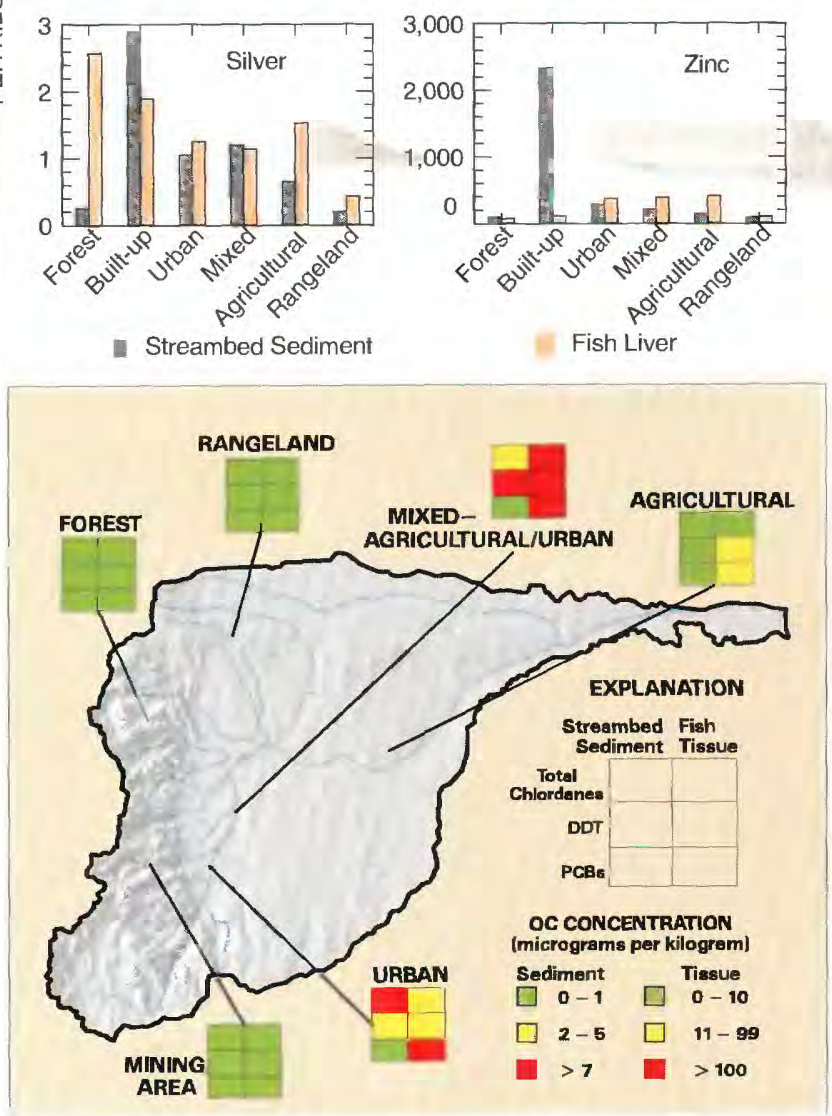

Distribution of selected organochlorine compounds $(O C$ 's) and trace elements in streambed sediment and fish tissue. Built-up land use includes the mining area.

\section{Information on technical reports and hydrologic data related to NAWQA can be obtained from: \\ Chief, South Platte NAWQA Study Unit \\ U.S. Geological Survey, WRD \\ P.O. Box 25046, MS 415 \\ Denver Federal Center, Denver, CO 80225 \\ (303) 236-4882 \\ http://webserver.cr.usgs.gov/nawqa/splt/splt_home.html}

\section{Information on National NAWQA Programs \\ may be obtained from:}

Chief, NAWQA Program

U.S. Geological Survey, WRD

12201 Sunrise Valley Drive, National Center, MS 413

Reston, VA 20192

(703) 648-5716

http://wwwrvares.er.usgs.gov/nawqa/nawqa_home.html

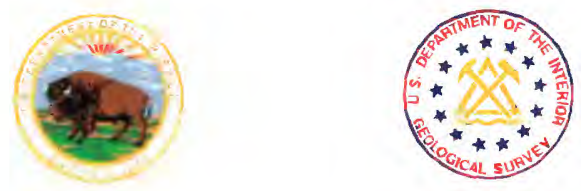

